\title{
Pest-közeli önkormányzatok viszonya egy inváziós fajhoz, a mirigyes bálványfához
}

\author{
Demeter András ${ }^{1}$, Czóbel Szilárd ${ }^{1}$, Limp Tibor $^{2}$, Csépányi Péter $^{2}$ és \\ Kovács Eszter ${ }^{1}$ \\ ${ }^{1}$ Szent István Egyetem, Természetvédelmi és Tájgazdálkodási Intézet, \\ 2103 Gödöllö, Páter K. u. 1. \\ ${ }^{2}$ Pilisi Parkerdö Zrt, \\ 2025 Visegrád, Mátyás $k$. út 4. \\ e-mail:demetex@gmail.com
}

\begin{abstract}
Összefoglaló: Az idegenhonos inváziós fajok terjedése a hazai és nemzetközi természetvédelem egyik legnagyobb problémája, ezért az ezzel kapcsolatos ismeretanyag bővítése szükségszerüvé vált. Hazánkban a mirigyes bálványfa komoly ökológiai és gazdasági károkat okoz. Terjedése gyakran lakott területekről, és utak mentén történik. Kutatásunk során a Pilisi Parkerdővel kapcsolatban álló 91, többségében Pest megyei önkormányzatnak küldtünk ki kérdőívet, mely a mirigyes bálványfa felismerésére, tulajdonságainak ismeretére, terjedésére, megfékezésére fókuszált. Kérdőívünket 68 önkormányzat töltötte ki. A válaszokból kiderült, hogy a fajt többnyire felismerik, de tulajdonságaival már kevésbé vannak tisztában az önkormányzatok illetékesei. A bálványfát felismerők nagy része megerősítette, hogy településén jelen van, föként utak mentén, lakott területen kívül találkoznak vele. Kevesen és többnyire nem a megfelelő módszerrel próbálták visszaszorítani, de érdekli öket a bálványfával kapcsolatos probléma, és nyitottak a megoldást elősegíteni.
\end{abstract}

Kulcsszavak: Mirigyes bálványfa, Ailanthus altissima, inváziós faj, kérdőív, önkormányzat

\section{Bevezetés}

A mirigyes bálványfa (Ailanthus altissima) közepes termetü, 25-30 m magasra is megnövő, kellemetlen szagú fa. Egyenes, szürke színü törzsén hosszanti irányú sárgásfehér repedések helyezkedhetnek el. Vesszeje vastag, sárgás- vagy vörösesbarna, bársonyos felületủ, bele rekeszes. Levelei szórt állásúak, 13-41 levélkéből páratlanul szárnyaltan összetettek. A levélkék tojásdad lándzsásak, kihegyezettek. Zöldessárga virágai laza bugákban nyílnak, belül gyapjasak. 3-4 cm-es, hoszszában csavarodott lependék termései csomókban helyezkednek el. (Udvardy \& Zagyvai 2012). 
Öshazája Északkelet-, Közép-Kína és Korea (Gencsi \& Vancsura 1992, Molnár \& Bariska 2002), de szinantróp areája jelenleg 5 kontinens mérsékeltövi és mediterrán éghajlatú területeit foglalja magába (Kowarik \& Böcker 1984). Világméretü telepítése során Magyarországra is eljutott, ahol először Bartosságh József (1841, 1843) ültette, villányi birtokára.

Hazánkban (Csiszár 2007, Udvardy \& Zagyvai 2012, Bartha et al. 2015) és Európában (Kowarik \& Säumel 2007, Lambdon et al. 2008, Sladonja et al. 2015) jelenleg az egyik legveszélyesebb fásszárú inváziós faj. A fővárosban gyakoribb idegenhonos taxonok közül üde, félszáraz és száraz vízgazdálkodású talajokon, beépített környezetben egyaránt a mirigyes bálványfa terjeszkedik a legagresszívebben (Udvardy \& Facsar 1995).

A fás szárú növények védelméról szóló 346/2008. (XII. 30.) Korm. rendelet, továbbá a fás szárú energetikai ültetvények telepítésének engedélyezése, telepítése, müvelése és megszüntetése részletes szabályairól, valamint ezen eljárások igazgatási szolgáltatási díjáról megalkotott 45/2007. (VI. 11.) FVM rendelet sem engedélyezi hazánkban az eredeti fajta telepítését, kertészeti változatait is csak az újulat folyamatos irtása mellett lehet ültetni.

Habár a bálványfa jó mézelőnek számít (Sztranics 2007a,b), méze nagyon ritka, mert a faj nagyobb lelöhelyei legtöbbször a városokban találhatók, ahova nehéz betelepíteni a méhcsaládokat (Jóna 2013).

Jó mézelő tulajdonságától eltekintve szinte minden területen problémát jelent tömeges megjelenésével. A védett és nem védett területeken is egyre nagyobb ökológiai károkat okoz (Korda et al. 2017), visszaszorítása pedig hatalmas öszszegeket emészt fel (Demeter et al. 2015). Faanyaga hamar korhad, ezért faipari jelentősége nincs, ugyanakkor nagy költséget jelent irtása, melynek értéke területtől függően, többszöri visszatéréssel, hektáronként összesen 300.000-1.500.000 forintot tesz ki. Ezért a Pilisi Parkerdő Zrt. a természetvédelmi célú fejlesztései során nagy területeken foglalkozott a bálványfa erdőterületekről történő kiszorításával. Terjedését segíti intenzív gyökérsarj-képzése, termésének nagyarányú csírázóképessége és perzisztens magbankja is. A felsoroltakon kívül gyökeréből más növényfajokra ható, növekedést gátló vegyületeket bocsájt a talajba (Udvardy 2004), melyet számos vizsgálat megerősít (Heisey 1990a,b, Gomez-Aparicio \& Canham 2008, Csiszár 2009, Csiszár et al. 2013)

A mirigyes bálványfa nagyon nehezen irtható. Csak mechanikus módon nem is ajánlott, mert a vágás után gyökeréből sarjtelepet hozhat létre, ami az állomány gyors terjedéséhez, megerősödéséhez vezethet. Vegyszeres (pl. glifozát alapú gyomirtó szerekkel) kezelése (permetezés, lomb- vagy kéregkenés, injektálás) viszont sikeresnek bizonyult, az „Özönnövények visszaszorításának gyakorlati 
tapasztalatai" címü ROSALIA sorozat 3. kézikönyvében több esettanulmány is bemutatja ennek eredményeit (Csiszár \& Korda 2015).

Gyakran lakott területekről, utak mentén terjed (Kowarik \& Säumel 2007) és könnyebben megtelepszik a nyílt, bolygatott talajfelszíneken (Udvardy 2004).

Terjedésében tehát fontos szerepet játszanak a települések zavart területei, ezért segíthet, ha tudjuk, hogy egy településen jelen van-e a faj, és ha igen, a települési önkormányzat illetékes szakemberei ismerik-e, illetve hogyan viszonyulnak hozzá. Emiatt a bálványfa elleni védekezés fontos elemének tartottuk az önkormányzatok szerepének tisztázását a faj terjedésében.

Kutatásunk célja:

- Felhívni a megkérdezett önkormányzatok figyelmét a fajra

- Feltárni a faj ismertségét és megítélését kiválasztott önkormányzatok körében

- A bálványfa elterjedésére vonatkozó további információkat gyüjteni

- Megismerni a kiválasztott települések bálványfához kötődő viszonyát

- Alapot adni a további hasonló kutatásokhoz, illetve segítséget nyújtani a faj visszaszorításához.

\section{Módszerek}

A faj terjedésében fontos szerepet játszó intézmények, vagyis az önkormányzatok megkérdezésében legcélravezetőbbnek a kérdőíves módszert gondoltuk, mivel így nagyobb mintaszámmal dolgozhattunk. Ezért egy 14 kérdésből álló, tematikus kérdőívet állítottunk össze (lásd függelék), melyben a kérdéseket a következő egységekbe soroltuk:

- A bálványfával kapcsolatos általános kérdések: a faj felismerése képről, pozitív és negatív tulajdonságai

- A faj előfordulására, terjedésére vonatkozó kérdések:

- A faj visszaszorítására vonatkozó kérdések

- Az önkormányzatok azonosítására vonatkozó kérdések

A kérdőívet 2016.10.20-án a Pilisi Parkerdő Zrt. körlevelével küldtük ki postai úton a Parkerdővel kapcsolatban álló 91 önkormányzatnak. Az általunk küldött kísérőlevélben a válaszadásra 2016.11.20.-i határidőt adtunk meg, és a Budakeszi Vadasparkba szóló belépőjegyek megnyerésének lehetőségével motiváltuk az illetékeseket a válaszadásra. Mivel nagyobb részük a megadott határidőn belül nem válaszolt, őket telefonon és email-en keresztül kértük ismételten az együttmüködésre, valamint online is kitölthetővé tettük a kérdőívet a Google segítségével. A 
megkérdezést egy mintaprojektnek tekintettük, ezért nem törekedtünk sem országos lefedettségre, sem reprezentativitásra.

A beérkezett válaszokat Microsoft Excel munkalapon rögzítettük, és a program segítségével alapstatisztikai számításokat végeztünk (gyakoriság, megoszlás, kereszttábla). A kapott eredményeket szintén az Excel program segítségével ábrázoltuk. Az eredmények kiértékelésénél azok megbízhatósága érdekében csak a bálványfát felismerők válaszait vettük figyelembe a 4., 5., 6., 7., 8., 9., 10., 12., és 13. kérdések esetében.

\section{Eredmények és értékelésük}

A megkérdezett 91 önkormányzat közül többszöri megkeresés eredményeként összesen 68-an válaszoltak, ami 75\%-os visszaküldési arányt jelent. A megkérdezett önkormányzatok közül 60 (66\%) volt Pest megyei, 16 (18\%) Komárom-Esztergom megyei, 13 (14\%) budapesti kerületi önkormányzat, 1 Heves és 1 Nógrád
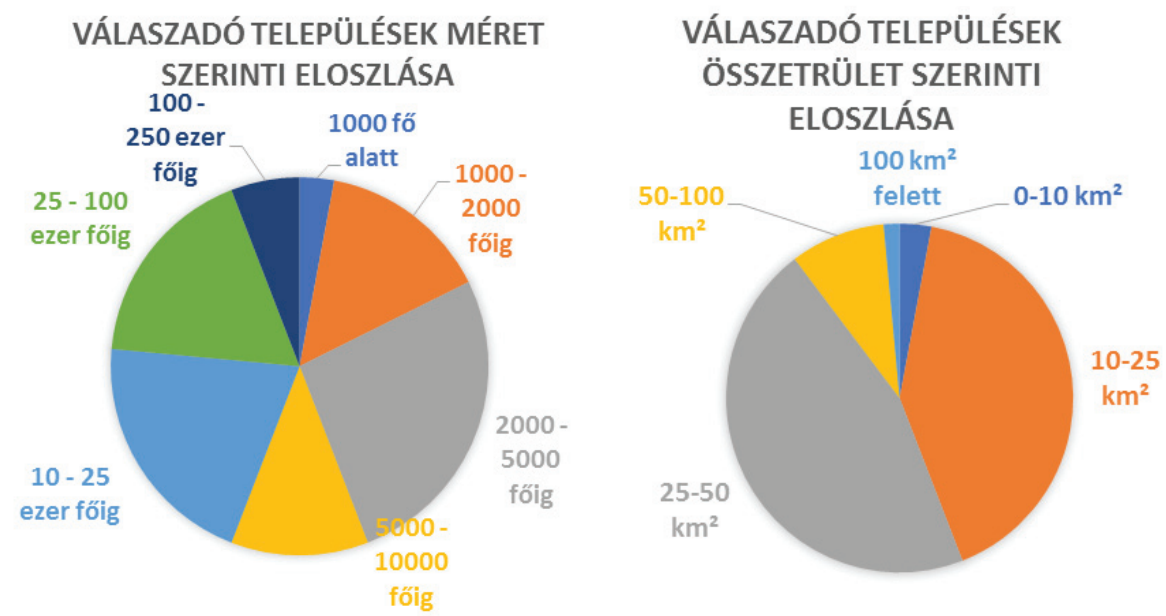

1. ábra. A válaszadó települések (Budapest esetén a kerületek) méret szerinti és összterület szerinti eloszlása.

megyei. A tényleges válaszadók közül 43 (63\%) Pest megyei, 13 (19\%) Komárom-Esztergom megyei, és 12 (18\%) budapesti kerületi. A válaszadó települések méreteinek (lakosság, összterület) eloszlását az 1. ábra szemlélteti.

A kitöltő személyek közül 50-en adták meg beosztásukat. Nagyobb részük (40\%) általános hivatali dolgozó (pl. jegyző, polgármester, ált. ügyintéző), és te- 
lepülésüzemeltetéssel kapcsolatos (32\%) munkakörben (pl. müszaki ügyintéző, településmérnök) dolgozó, kisebb részük (28\%) az ökológiában jártasabb (pl. fökertész, zöld referens, környezetvédelmi ügyintézö).

A kitöltött kérdőívek nagy része (43 db) email-ben (Word vagy Pdf. formátumban) érkezett, 15 -en online töltötték ki, és 10 válasz érkezett postai úton.

\section{A bálványfával kapcsolatos általános kérdések}

A válaszadó 68 önkormányzat közül 53 ismerte fel a fajt, amit az 1.táblázat szemléltet. A táblázatban a fajt felismerők és fel nem ismerők 2. és 3. kérdésre adott válaszainak számát vetettük össze.

A táblázat alapján elmondható, hogy azok, akik nem ismerték fel a fajt, sokkal óvatosabban jelölték a tulajdonságokat, a számukhoz képest is kisebb arányban. A negatív hatásoknál mindkét csoport (akik felismerték a fajt és akik nem) döntő

1. táblázat. A bálványfa felismerése és ismerete a kérdőívet kitöltő önkormányzatok körében.

*Egyéb válaszokból származó kategória

\begin{tabular}{|c|c|c|c|}
\hline & & 1. $\mathrm{F}$ & $\begin{array}{l}\text { rte-e a } \\
\text { fát }\end{array}$ \\
\hline & & Igen & Nem \\
\hline & & 15 & 53 \\
\hline & Kiszorítja az őshonos fajokat & 14 & 51 \\
\hline & Csírázásgátló vegyületeket juttat a talajba & 2 & 19 \\
\hline 2. Ön szerint & Sokan allergiásak rá & 0 & 6 \\
\hline $\begin{array}{l}\text { milyen negativ } \\
\text { hatásai lehetnek }\end{array}$ & Jelentős anyagi károkat okoz az agrár szektorban & 1 & 17 \\
\hline $\begin{array}{l}\text { a bálványfa ha- } \\
\text { zai teriedésének? }\end{array}$ & *Közterületeken, épületekben problémát okoz & 0 & 3 \\
\hline (Több választ is & *Gyomosít & 0 & 3 \\
\hline bejelölhet) & *Erdőgazdálkodást nehezíti & 0 & 2 \\
\hline & Nem tudok negatív hatásról & 0 & 2 \\
\hline & Jó mézelö & 5 & 23 \\
\hline 3.Ön szerint & Jól értékesíthető faanyagot ad & 2 & 9 \\
\hline milyen pozitív & Egzotikus megjelenésű & 1 & 9 \\
\hline hatásai lehetnek & Fajgazdag élőhelyeket teremt & 0 & 1 \\
\hline zai terjedésének? & Árnyékot ad & 4 & 21 \\
\hline (Több választ is & *Várostürő & 0 & 2 \\
\hline bejelölhet) & Egyéb, éspedig..... & 1 & 5 \\
\hline & Nem tudok pozitív hatásról & 6 & 14 \\
\hline
\end{tabular}


többsége gondolta úgy, hogy a bálványfa kiszorítja az őshonos fajokat. Ez részben annak tudható be, hogy a kísérólevélben veszélyes inváziós fajként említjük, másrészt viszont úgy tünik, hogy tisztában vannak az idegenhonos inváziós fajok egyik legveszélyesebb általános hatásával. A fajt felismerő csoport 19 tagja ismerte a faj allelopátiás hatását, és 17-en tisztában voltak azzal is, hogy már most jelentős anyagi károkat okoz, tehát ökológiai és ökonómiai hatásait is legalább részben ismerik. A pozitív hatások közül mindét csoport leginkább jó mézelö, és árnyékoló tulajdonságát emelte ki. Utóbbi nem meglepő, hiszen a fák általában nagyobb árnyékot vetnek.

Azok közül, akik nem ismerték fel a fajt, egy válaszadó a fotoszintetizálást nevezte meg külön a faj pozitív hatásaként az egyéb válaszok között. A bálványfát felismerők a következő egyéb pozitív hatásokat említették:

- oxigént termel, $\mathrm{CO} 2$-t köt meg és

- magas a cellulóz tartalma.

Jelen van az Önök településén a bálványfa?

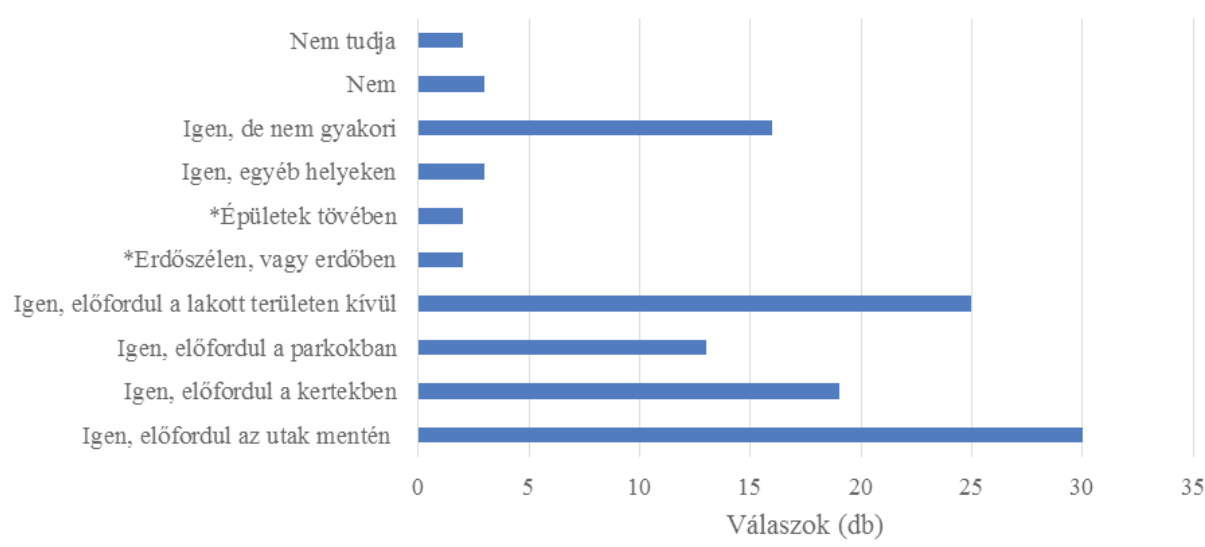

2. ábra. A bálványfa előfordulására vonatkozó válaszok a fajt felismerők körében (Több választ is bejelölhettek.).

A faj elöfordulására, terjedésére vonatkozó kérdések

A bálványfát felismerő önkormányzatok nagy része szerint jelen van településükön, csupán 5-en voltak, akik nem tudták ezt megerösíteni (2.ábra). A válaszok alapján leginkább utak mentén és a lakott területeken kívül található meg. A megadott kategóriákat az „Egyéb” válaszok alapján bővítettük a *-al jelöltekkel, valamint a faj előfordulási helyeként 1-1 esetben említették még a vasúti töltéseket és természetvédelmi területeket is. 
Ön szerint hogyan került be a településükre a bálványfa?

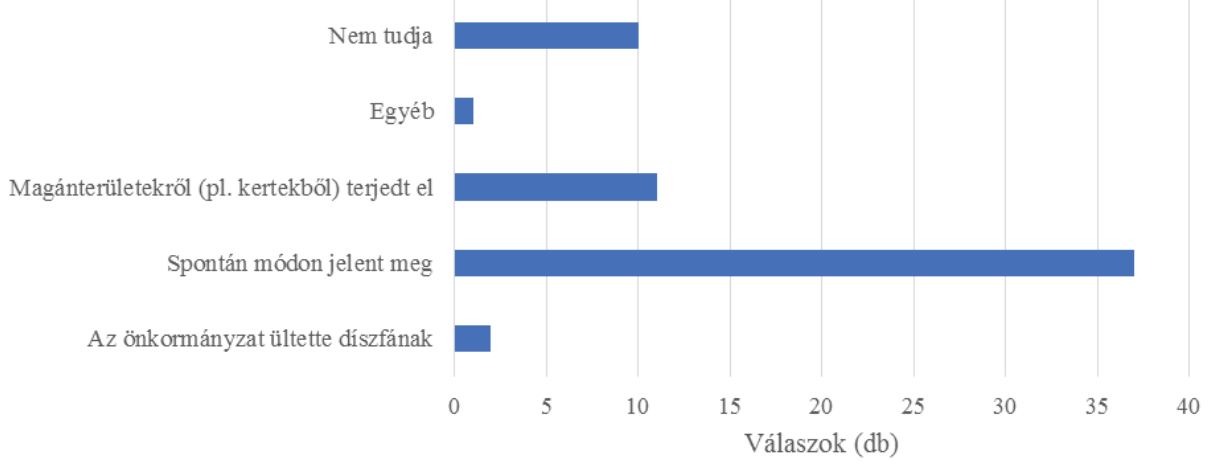

3. ábra. A bálványfa településre bekerülésének lehetséges okai a fajt felismerők szerint (Több választ is bejelölhettek.).

A 3. ábrán a faj megjelenésnek okai láthatók. Az ábrán csak azoknak az önkormányzatoknak a válaszai szerepelnek, akik felismerték a fajt.

A válaszadók túlnyomó része szerint a bálványfa spontán, tehát a település beavatkozása nélkül jelent meg. Ennek legvalószínübb oka a magok szél általi terjedése. Az „Egyéb” kategóriát választó kitöltő szerint díszfaként ültetett egyedek fertőzték meg a környező területeket.

Arra a kérdésre, hogy tudja-e, mikor került be a bálványfa a településre döntöen $(50 \mathrm{db})$ nemleges választ kaptunk a fajt felismerő önkormányzatoktól. Ennek oka valószínüsített spontán megjelenésével is magyarázható. Egy helyről pedig az 1970-es évekre datálták a betelepülést.

A fajt felismerő válaszadók szerint településük területén leginkább magról terjed, de a sarjadzást is sokan jelölték be (4. ábra). Az, hogy mindössze 1 jelölést

\section{Hogyan terjed a faj a településen?}

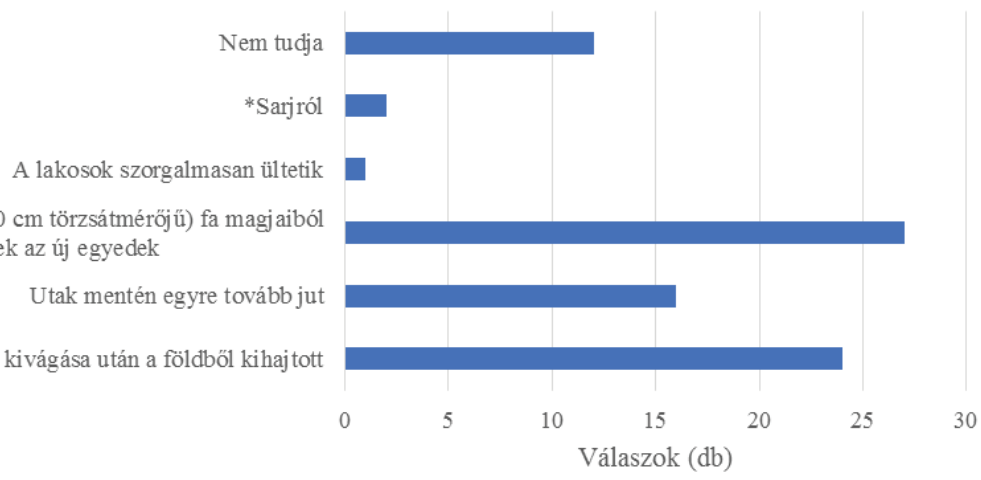

4. ábra. A faj terjedésére vonatkozó válaszok (Több választ is bejelölhettek.). 
kapott az ültetésre vonatkozó válasz, utalhat a faj erőteljes terjedési képességére, mellyel emberi segítség nélkül is hatékonyan hódítja meg az újabb területeket.

A „Rendelkezik-e a település a bálványfa megjelenését, terjedését nyomon követő eszközzel (pl. rendszeres felmérés), vagy a visszaszorítására irányuló önkormányzati intézkedéssel, rendelettel?" kérdésre többnyire nemleges (44 db) választ kaptunk a fajt felismerö önkormányzatoktól, 8-an viszont igennel feleltek. Utóbbiak közül 3 önkormányzatnak van a faj kezelésére vonatkozó rendelete, mások pedig a rendszeres terepszemlét, Kerületi Zöldvagyon Katasztert, fasorfenntartási munkálatok közben végzett bálványfairtást és természetvédelmi területek kezelési tervét említették. Egy önkormányzat online lakossági bejelentő platformmal igyekszik nyomon követni a faj terjedését.

\section{A faj visszaszoritására vonatkozó kérdések}

A fajt felismerő válaszadó önkormányzatoknak csak kis része (a táblázat alapján maximum 18) foglalkozott vagy foglalkozik rendszeresen a bálványfa visszaszorításával (5. ábra) annak ellenére, hogy a 4. kérdésből kiderült, szinte mindenhol

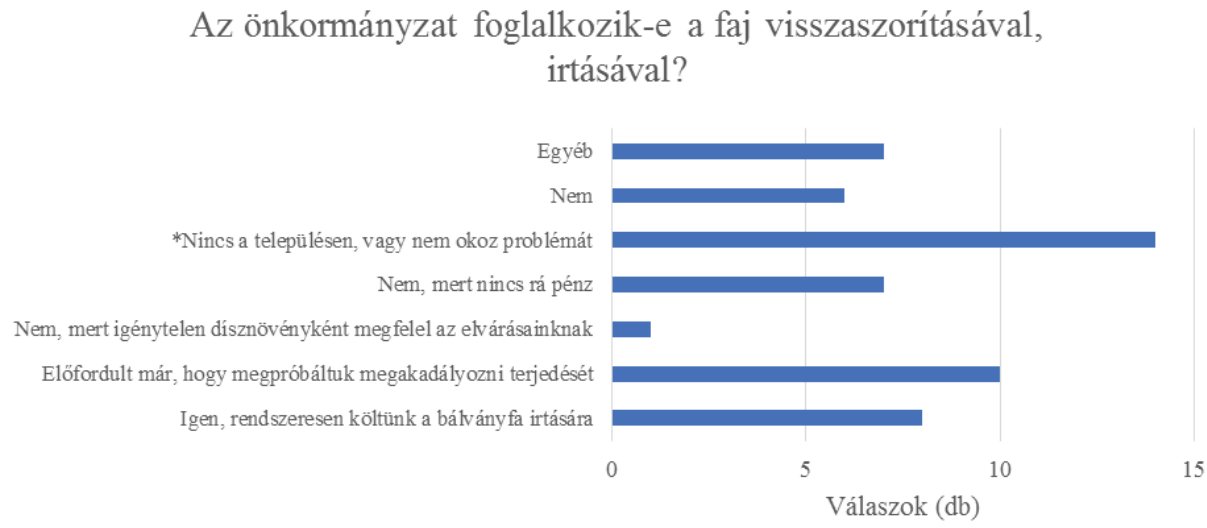

5. ábra. A faj kezelésére vonatkozó válaszok.

megtalálható. Ennek lehetséges oka többnyire, hogy még kevéssé tömeges, vagy az önkormányzatok nem tekintik problémának a jelenlétét. Az „Egyéb” válaszok leginkább a fajjal és kezelésével kapcsolatos információk hiányáról szólnak.

A faj visszaszorítását önkormányzati forrásból, azon belül közterület-, park-, és fasor fenntartási keretből végzik.

A „Ha irtják a bálványfát, milyen módszereket alkalmaznak?” kérdésre meglepő módon jóval többen (29-en) válaszoltak, mint amennyi az előző kérdésre adott válaszokból (18) következik. A bálványfa visszaszorítása terén egyértelmüen a 
mechanikai módszerek alkalmazása van túlsúlyban a fajt felismerő önkormányzatoknál (6. ábra).

Ha irtják a bálványfát, milyen módszereket alkalmaznak?

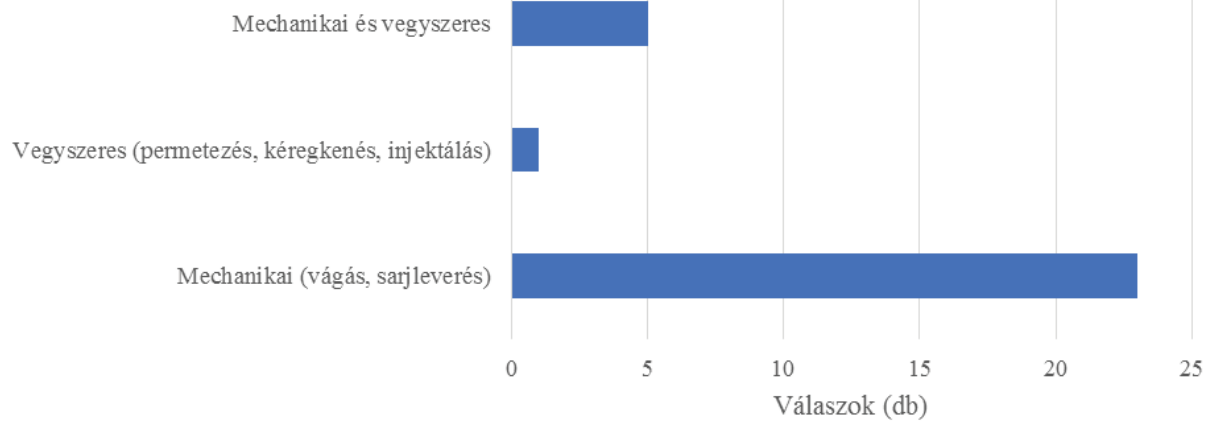

6. ábra. A bálványfa irtásának önkormányzatok által alkalmazott módszerei.

Ezek más fajok kezelésében általánosan használtak, viszont ennél a fajnál a vegyszeres kezelések nélkül gyakran hatástalanok, sőt elősegítik a sarjadzását (Csiszár \& Korda 2015). Tehát az esetek nagy részében nem megfelelően kezelik a fajt.

A következő kérdés jó alapja a visszacsatolásnak, hiszen az önkormányzatok nagyobb része szívesen tudna meg többet a bálványfa ökológiai hatásairól és az ellene való védekezés lehetséges módjairól (7. ábra). Utóbbi fontossága az előző

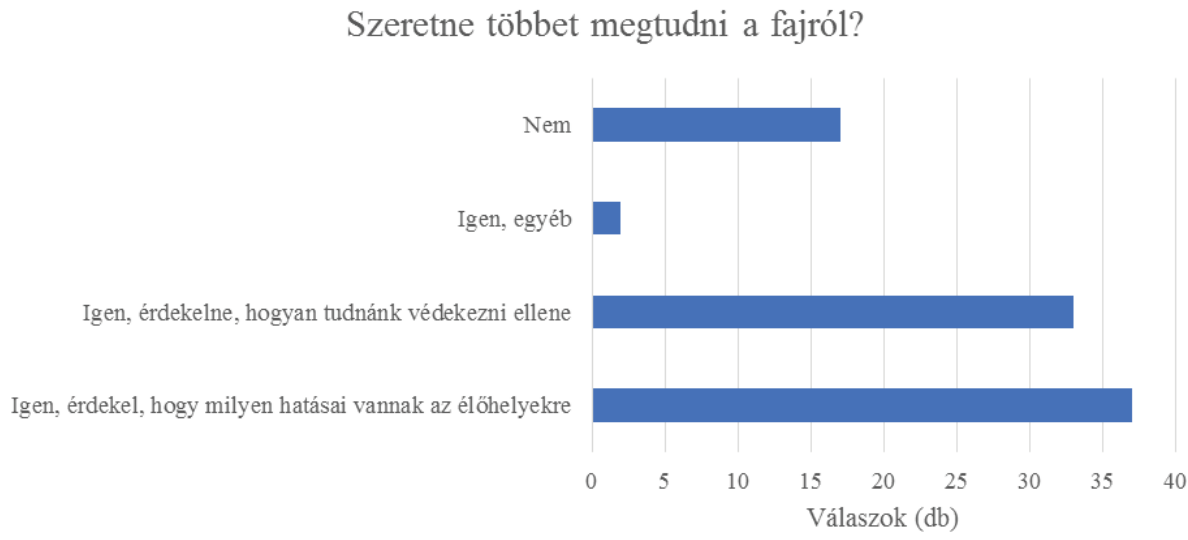

7. ábra. A válaszadó önkormányzatok igénye a bálványfával kapcsolatos információkra. 
kérdésből is kiderült, hiszen a faj kezelésével foglalkozó önkormányzatok nagy része nem megfelelő módon (kizárólag mechanikus módszerekkel) teszi azt.

Az egyéb kategóriát bejelölőket érdekli még a faj irtására fordítható pénzforrás, pályázati lehetőség; valamint egy egységes eljárásrend, mely összehangolja az erdészetek és a természetvédelem és a földhivatalok munkáját az önkormányzatokéval.

A bálványfát felismerő önkormányzatok nagy része fontosnak tartja a helyi erdészetekkel és természetvédelemmel való együttmüködést a faj kezelésében (8. ábra), sőt több, mint fele a lakosság bevonását is szorgalmazná. Az együttmúkö-

Szükség van-e Ön szerint együttműködésre a faj kezeléséhez?

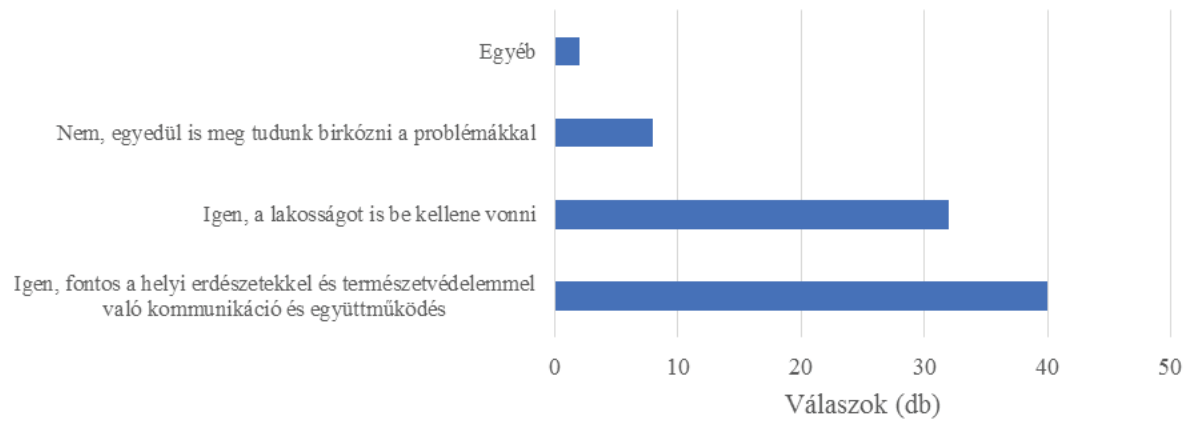

8. ábra. A fajt felismerő önkormányzatok együttmüködési hajlandósága

(Több választ is bejelölhettek.).

dés hasznos lenne, mert az erdészetek és természetvédelmi szakemberek tudására és eszközeire, valamint a lakosság együttmüködésére (pl. akik gyakran jó szándékkal ültetik, gondozzák a bálványfa egyedeket) szükség van a hatékony visszaszorításhoz. Az egyéb kategóriát jelölők válaszai: „A lakosság bevonására nem az anyagiak miatt van szükség, hanem az információk átadása miatt.”, „Egyelöre nem látom a településen ezt nagy problémának."

Arra a kérdésre, hogy: „Megoldhatónak tartja-e a bálványfa irtását közmunkaprogramokban végezni?” a többség (32-en) igennel válaszolt, míg 19-en ezt nem tartották lehetségesnek. Valóban, a visszaszorítás mechanikai részét és a monitoringot szinte bárki el tudja végezni, de a vegyszeres kezeléshez speciális ismeretek kellenek.

Az utolsó kérdésnél a kitöltőknek lehetőségük nyílt egyéb tapasztalataikat, ötleteiket vagy kéréseiket, észrevételeiket megosztaniuk velünk. Az egyik kitöltő szerint a bálványfa képes beton környezetben is megmaradni, egy másik pedig a 
településükön erősebben terjedő aranyvesszőre és selyemkóróra hívta fel a figyelmet. Egy kitöltő az inváziós fajok, így a bálványfa elterjedésének feltérképezésére jó módszernek gondolja az online lakossági bejelentést. Egy másik válaszadó hangsúlyozta a bálványfa kezelése kapcsán az erdészetek és nemzeti park igazgatóságok bevonásának fontosságát, mivel településük külterületének jelentős része országos jelentőségű védett természeti terület, illetve állami erdő. Két kitöltő szerint országosan kellene kötelezővé tenni az irtását. A faj irtása kapcsán az egyik kitöltő megjegyezte, hogy az természetvédelmi területen nehézkes, és hatékony megoldást csak a hosszú, távú kombinált (mechanikai és vegyszeres) kezelés nyújt. A kezelés elvégzésében segíthet a közmunkaprogram, de foglalkoztatóként az illetékes állami erdészeti társaságokat célszerű kijelölni. Végül egy kitöltő szavait idézve: „Fontos az özönnövények problémájának hatékonyabb kommunikációja, gyermekek és felnöttek körében egyaránt."

\section{Következtetések}

Kérdőíves felmérésünkkel 91 hazai önkormányzatot kerestünk meg, és hívtuk fel figyelmüket hazánk egyik legveszélyesebb fásszárú inváziós növényfajára, a mirigyes bálványfára. 68 önkormányzat töltötte ki a kérdöívünket. Az eredmények értékelése során kiderült, hogy a válaszadó önkormányzatok nagyobb része felismeri a fajt, és tisztában van azzal, hogy veszélyezteti az őshonos vegetációt, egyéb hatásait és tulajdonságait viszont kevéssé ismerik. Feltehetően részben ezért nem fordítanak elég figyelmet terjedésének megakadályozására. Agresszív térnyerését bizonyítja, hogy a bálványfát felismerők 91\%-a szerint jelen van a településükön, valamint, hogy megjelenése a válaszadók szerint túlnyomórészt spontán történt. Kowarik \& Säumel (2007) szerint jellemzően lakott területekről, utak mentén terjed, amit a mi kutatásunk is megerősít. A kérdőíves válaszok igazolják, hogy a faj könnyen megtelepszik a bolygatott talajfelszíneken, amit Udvardy (2004) már korábban jelzett. A kérdőíves válaszok alapján leginkább magjaival terjed ezért úgy gondoljuk, hogy különösen hasznos lenne az idősebb, maghozó egyedeket lokalizálni, és vegyszeresen kiirtani. A bálványfát felismerő önkormányzatok nagyobb része nem foglalkozik a faj visszaszorításával, de ha mégis, azt többnyire mechanikus - tehát nem megfelelö, a szakirodalom (Csiszár \& Korda 2015) alapján sem javasolt - módszerrel végzik. Az előbbi negatívumok mellett viszont a válaszadók többsége szükségesnek tartja a fajjal kapcsolatos ismereteinek bővítését, a helyi erdészeti és természetvédelmi szakemberekkel való együttmüködést. Sokan a lakosságot is bevonnák a fajjal szembeni intézkedésekbe. 
A mirigyes bálványfa hazai terjedésének megakadályozásában a települések önkormányzatának és lakosságának kulcsszerepe van, ezért hasznos lenne a kérdőíves felmérést minden önkormányzatra kiterjeszteni. További kutatások vonatkozhatnak a fertőzöttség mértékének és a visszaszorítási költségeknek a becslésére, mely az irtási munkák tervezése miatt lényeges.

Nehézséget jelenthet a bálványfák szórt elhelyezkedése, ezért az önkormányzatok biztosabb fajfelismerésére és a településük területén lévő állományok pontosabb ismeretére (pl. elhelyezkedés, korösszetétel) van szükség. Ennek elősegítésére a válaszadó önkormányzatoknak visszacsatolásként a faj ökológiai és ökonómiai hatásait és az ellene való hatékony védekezés eszközeit bemutató ismeretterjesztő anyagot juttatunk el. Ezen túl fontos lenne az önkormányzatok illetékes munkatársait a témában továbbképezni. Az önkormányzatok helyi illetékességű nemzeti park igazgatóságokkal és erdészetekkel való együttmüködését a mirigyes bálványfa visszaszorításában elengedhetetlennek tartjuk, különösen a vegyszeres kezelés legális és hatékony kivitelezésében. Javasoljuk továbbá pályázati lehetőségek bővítésével is ösztönözni az önkormányzatokat a mirigyes bálványfa visszaszorítására.

Habár az idegenhonos inváziós fajok betelepítésének vagy behurcolásának és terjedésének megelőzéséről és kezeléséről alkotott 1143/2014/EU rendeletének mellékletében jelenleg nem szerepel a faj, de a rendelet szerint minden tagország alkothat saját nemzeti jegyzéket, sőt más tagországokkal közösen regionális együttmüködésre is lehetőség van a faj visszaszorítása érdekében.

Köszönetnyilvánitás - Köszönettel tartozunk a Pilisi Parkerdő Zrt.-nek a kérdőívek kitöltetésében nyújtott segítségükért, valamint a válaszadó önkormányzatok illetékes munkatársainak.

\section{Irodalomjegyzék}

Bartha, D., Király, G., Schmid,t D., Tiborcz, V., Barina, Z., Csiky, J., Jakab, G., Lesku, B., Schmotzer, A., Vidéki, R., Vojtkó, A., \& Zólyomi, Sz. (szerk.) (2015): Magyarország edényes növényfajainak elterjedési atlasza. - Nyugat-magyarországi Egyetem Kiadó, Sopron, 329 p.

Bartosságh, J. (1841): Beobachtungen und Erfahrungen über den Götterbaum (Ailanthus glandulosa L.). - Ofen, Gyurián u. Bagó. III, 47 p.

Bartosságh, J. (1843): Folytatólagos értesítés a' bálványfa (Ailanthus glandulosa, Götterbaum) terjedése körül. - Magyar Gazda 3: 298-300.

Csiszár, Á. (2007): Özönnövénnyé vált a sátoros felleng. - Erdészeti Lapok 142: 78-80.

Csiszár, Á. (2009): Allelopathic effects of invasive woody plant species is Hungary. - Acta Silv. Lign. Hung. 5: 9-17.

Csiszár, Á. \& Korda, M. (szerk.) (2015): Özönnövények visszaszorításának gyakorlati tapasztalatai. - Duna-Ipoly Nemzeti Park Igazgatóság, Budapest, 239 p. 
Csiszár, Á., Korda, M., Schmidt, D. Šporčić, D.,Süle, P. , Teleki, B., Tiborcz, V., Zagyvai, G., \& Bartha, D. (2013): Allelopathic potential of some invasive neophytes occurring in Hungary. - Allelopathy J. 31: 309-318. doi: http://dx.doi.org/0971-4693/94

Demeter, A., Sarlós, D., Skutai, J., Tirczka, I., Ónodi, G. \& Czóbel, Sz. (2015): Kiválasztott özönfajok gazdasági szempontú értékelése - Tájökológiai Lapok 13: 193-201.

Gencsi, L. \& Vancsura, R. (1992): Dendrológia. - Mezőgazda Kiadó, Budapest, 728 p.

Gomez-Aparicio, L. \& Canham, C. D. (2008): Neighbourhood analyses of the allelopathic effects of the invasive tree Ailanthus altissima in temperate forests. - J. Ecol. 96: 447-458. doi: http:// dx.doi.org/10.1111/j.1365-2745.2007.01352.x

Heisey, R. M. (1990a): Allelopathic and Herbicidal Effects of Extracts from Tree of Heaven (Ailanthus altissima) - Am. J. Bot. 77: 662-670. doi: http://dx.doi.org/10.3732/ajb.1300450

Heisey, R. M. (1990b): Evidence for allelopathy by tree-of-heaven (Ailanthus altissima). - J. Chem. Ecol. 16: 2039-2055. doi: http://dx.doi.org/10.1007/BF01020515

Jóna, A. K. (2013): A bálványfa (Ailanthus altissima) természetvédelmi, gazdasági és társadalmi hatásai. - szakdolgozat. Szent István Egyetem, Gödöllö, 64 p.

Korda, M., Kézdy, P. \& Csiszár Á. (2017): Idegenhonos, inváziós fajok hazánk védett területein. Erdészeti Lapok 152: 107-109.

Kowarik, I. \& Böcker, R. (1984): Zur Verbreitung, Vergesellschaftung und Einbürgerung des Götterbaumes (Ailanthus altissima (Mill.) SWINGLE) in Mitteleuropa. - Tuexenia 4: 9-29.

Kowarik, I. \& Säumel, I. (2007): Biological flora of Central Europe: Ailanthus altissima (Mill.) Swingle. - Perspect. Plant Ecol. 8: 207-237. doi: http://doi.org/10.1016/j.ppees.2007.03.002

Lambdon, P. W., Pyšek, P., Basnou, C., Hejda, M., Arianoutsou, M., Essl, F., Jarošík, V., Pergl, J., Winter, M., Anastasiu, P., Andriopoulos, P., Bazos, I., Brundu, G., Celesti-Grapow, L., Chassot, P., Delipetrou, P., Josefsson, M., Kark, S., Klotz, S., Kokkoris, Y., Kühn, I., Marchante, H., Perglová, I., Pino, J.,Vilà, M., Zikos, A., Roy, D. \& Hulme, P. E. (2008): Alien flora of Europe: species diversity, temporal trends, geographical patterns and research needs. - Preslia 80: 101-149.

Molnár, S. \& Bariska, M. (2002): Magyarország ipari fái. - Szaktudás Kiadó Ház, Budapest, 210 p.

Sladonja, B., Sušek, M. \& Guillermic, J. (2015): Review on Invasive Tree of Heaven (Ailanthus altissima (Mill.) Swingle) Conflicting Values: Assessment of Its Ecosystem Services and Potential Biological Threat. - Environ. Manage. 56:1009-1034. doi: http://dx.doi.org/10.1007/ s00267-015-0546-5

Sztranics, Zs. (2007): A bálványfa. - Méhészet 55: 16-17.

Sztranics, Zs. (2007): A bálványfa II. - Méhészet 55: 18.

Udvardy, L. (2004): Bálványfa. - In: Mihály, B. \& Botta-Dukát, Z. (szerk.): Özönnövények. - TermészetBÚVÁR Alapítvány Kiadó, Budapest, pp. 143-160.

Udvardy, L. \& Facsar, G. (1995): Weed vegetation of Budapest as an indicator of changes in environments's quality. $-9^{\text {th }}$ EWRS (European Weed Research Society) Symposium Budapest 1995: „Challenges for Weed Science in a Changing Europe. Perspektiven für die Unkrautforschung im veranderten Europa." 10-12 July 1995, Proceedings 1: 107-112.

Udvardy, L. \& Zagyvai, G. (2012): Mirigyes bálványfa (Ailanthus altissima [Mill.] Swingle). - In: Csiszár, Á. (szerk.): Inváziós növényfajok Magyarországon. - Nyugat-magyarországi Egyetem Kiadó, Pátria Nyomda Zrt., Budapest, pp. 132-137.

\section{Függelék}

A cikkhez tartozó online függelék a folyóirat honlapján található.

Függelék 1: Az önkormányzatoknak kiküldött kérdöív. 


\title{
The attitude of local governments near Budapest to an invasive species, tree of heaven
}

\author{
András Demeter ${ }^{1}$, Szilárd Czóbel ${ }^{1}$, Tibor Limp², Péter Csépányi² and \\ Eszter Kovács ${ }^{1}$ \\ ${ }^{1}$ Institute of Nature Conservation and Landscape Management, Faculty of Agricultural \\ and Environmental Sciences, Szent István University, \\ H-2100 Gödöllö, Páter Károly u. 1, Hungary. \\ ${ }^{2}$ Pilisi Parkerdö Zrt, \\ H-2025 Visegrád, Mátyás k. út 4, Hungary \\ e-mail: demetex@gmail.com
}

The spread of invasive alien species is one of the biggest problems of national and international nature conservation therefore the expansion of the relevant knowledge became necessary. In Hungary tree of heaven (Ailanthus altissima)causes serious ecological and economical damage. It spreads often from inhabited areas and along roads. During our research a questionnaire was sent to 91, Pilisi Parkerdö related local governments which mostly located in Pest county of Hungary. The questionnaire focused on the recognition and the knowledge the characteristics, spreading and elimination of tree of heaven. The answers revealed that the species was mostly recognized, but its characteristics were less well known to the officials of local goverments. Most of those, who recognized the tree of heaven confirmed that it was present in their settlement, mainly along the roads and outside the residential area. Just a few of them tried to eradicate the species, but even those mostly did not apply the proper method. Nevertheless, they are interested in the problem related to the tree of heaven and are open to find solution to it.

Keywords: Tree of heaven, Ailanthus altissima, invasive species, questionnaire, local governments 